\title{
THE CONSEQUENCES OF TOXIC LEADERSHIP ON FOCI OF COMMITMENT
}

\author{
*Mert KILIC (Orcid ID 0000-0002-9516-9719) \\ *Hilal GOKKAYA (Orcid ID:0000-0003-1997-4641) \\ *Ayşe GUNSEL (Orcid ID: 0000-0002-4427-7322) ${ }^{1}$ \\ *Kocaeli University, Kocaeli, Turkey
}

\begin{abstract}
Leadership is an important subject that has been studied more by many researchers for many years While the focus on positive leadership styles still dominates leadership research; an increasing number of studies have begun to investigate different forms of negative leadership behaviours. Revealing the effects of toxic leadership on organizational commitment is the primary focus of this paper. This study investigates the relationship between toxic leadership and organizational commitment from several foci-commitment to organization, commitment to supervisor, and commitment to co-workers- to develop a better understanding for negative aspects of leadership in banking industry. To do so, a survey is conducted on 277 employees of banking industry based on the assumption that that kind of work environment is convenient for toxic leaders to emerge. The findings provide empirical evidence regarding significant and negative associations between toxic leadership and all the foci of commitment. Moreover, the findings highlight that the impact of toxic leadership behaviours on commitment to supervisor is stronger than the associations of toxic leadership with other foci of commitment.
\end{abstract}

Keywords: Toxic leadership, organizational commitment, foci of commitment

\section{INTRODUCTION}

Organizational commitment has drawn significant attention from academics and practitioners for decades. The antecedents of organizational commitment attract similar attention either (Yang et al., 2011). Without a doubt, promising leaders within organizations have committed followers. It is not unexpected. So, theorists who claim a specific approach to leadership (e.g., charismatic, transformational, ethical, visionary) generally involve leadership as a potential precursor of organizational commitment (Bass and Riggio, 2005; Jackson et al., 2013). Most leaders are competent, experienced, and ethical in their behaviours, but leaders who are self-serving, arrogant, incompetent also exist. So, the emphasis on positive leadership is still prevalent in management and organizational behaviour studies; while a recent stream of research recognizes that there is also a dark side to leadership, such as destructive, narcist, and toxic leaders (Schyns and Schilling, 2013). Indeed, competitive and harsh business environments witness an increase in dysfunctional, destructive and toxic behaviours by those in positions of power and influence which requires more studies regarding the individual and organizational outcomes (Mehta and Maheshwari, 2013)

Revealing the effects of toxic leadership on organizational commitment is the primary focus of this paper. We examine organizational commitment from several foci-commitment to organization, commitment to supervisor, and commitment to co-workers- to develop a better understanding as there is scant research available on negative aspects of leadership (Mehta and Maheshwari, 2013). This paper is arranged in four parts. Following this section, the dark side of the leadership is discussed, and the features and the dimensions of toxic leadership are defined. Next, we describe the methodology applied to explore the relationships among toxic leadership and organizational. Based on data conducted on 277 employees of the banking industry, we test the relationships among toxic leadership and organizational commitment. Finally, the conclusions are set out, along with some recommendations for future research. 


\section{PROBLEM STATEMENT}

\section{Toxic Leadership}

Leadership is an important subject that has been studied more by many researchers for many years (Horner,1997). There are many definitions regarding leadership within the literature, but generally, a leader and the followers takes place the common description (Barnes and Kriger, 1986). Acorrding to Byars (1987), leadership is the capability of affecting the ideas and attitudes of the organizational members. Although leadership has been a focal topic of Organizational Behaviour (OB) discipline since the inception of the field, only recently have researchers begun to directly explore the dark side of the leadership (Pelletier, 2010; Schmidt, 2008).

Some of the leaders can manage their subordinates in a positive and effective manner and offer advantageous opportunities that can be beneficial for the organization, while others present "Toxic" characteristics, which is already defined as "Toxic Leadership" (Lipman-Blumen, 2006). Kusy and Holloway (2009) refer to the toxic leader as the "tip of the toxic iceberg". They suggest that the lasting human and financial costs of toxic leadership are "below the waterline" as toxic leaders do the most damage to organizations (Aubrey, 2012).

Toxic leader's destructive behaviours and characteristics can make individuals, groups, organizations, communities seriously and permanently damaged (Kellerman, 2004). In order to be entitled as a toxic leader, the leader should show his/her toxic effect in a way that would affect the organization, not just a particular employee (Reed 2004). Toxic, poisonous leaders are the leaders who lead and harm the employees, the business environment, and the organizational climate. It is necessary to differentiate the toxic leader from the boss or manager who is bad and oppressive. Toxic leaders are spreading this poison with an excessive control mechanism (Karen, 2003). Toxic leaders are inwardly motivated, inherently destructive, and violate the legitimate interests of the organization.

Especially in the US, toxic leadership studies are mostly addressed in the military and health sectors (Paunonen et al.,2006, Reed, 2004). We can see that toxic leadership has negative effects on both individual and organizational outputs, such as organizational commitment, organizational climate, organizational motivation, organizational culture (Lipman-Blumenn, 2006; Erickson et al.,2007; Einarsen et al.,2007).

\section{Commitment}

The concept of commitment was first examined by Whyte in 1956 and subsequently developed by many researchers (Mowday, 1998). According to Scholl, organizational commitment is defined as ongoing actions and the power to be kept in balance as a result of providing the expected or equal conditions for any reason (Scholl, 1981). Allen and Meyer explain organizational commitment as the behaviour that enables employees to maintain working in the same workplace as a permanent member of the organization by transforming the relationship of employees with the organization into commitment (Meyer and Allen, 1997). If there is organizational commitment in a workplace, it is difficult for employees to quit. Hereby, this situation makes a positive contribution to the workplace by reducing the costs of the workplace. Furthermore, individuals with high commitment, exhibit devoted behaviours about their work (Meyer and Allen, 2004).

Allen and Meyer's approach to organizational commitment focuses on three dimensions. These are affective, continuance, and normative commitment. According to Meyer and Allen (1997), the relationship of an employee with his organization can accommodate different levels of these three dimensions. Meyer and Allen's hypothesis suggests that each of these three dimensions is the result of different experiences, and these experiences may have different effects on business behaviours. Affective commitment includes personal, structural, and work-related characteristics as well as work experiences. Via such a commitment, the employees assimilate all values within the organization and agree to be a part of the business. The organization members who have emotional ties to their organizations wish to continue their membership relationship with their organizations and believe in the goals of the organization. Continuance Commitment is a commitment that results from employees' past experiences in organizations (Becker, 1960). In this commitment, employees are concerned that they will lose their sense of labour, money, title, and recognition when they quit (Powell and Meyer, 2004). Employees consider that the continuity of their employment in the organization is mandatory because of the benefits that the employees have obtained, and the alternative gains are low and difficult (Meyer \& Allen, 1991). Normative commitment is a compulsory commitment. 
This commitment is based on convincing employees that they are obliged to stay in their organizations by believing that they have certain obligations to their organizations. An individual who feels a moral imperative can remain in the same organization for a long time, believing that he is doing the right thing and believing that commitment to the organization is loyalty and virtue (Allen and Meyer, 1990).

As a result of many studies conducted in the field of organizational commitment, solutions to the some of complexities that arise for many years have been explained by Becker (1992) with Foci and Bases of Commitment (Becker, 1992). After this explanation, the researches about commitment are done mostly about the foci of commitments such as commitment to the senior management, supervisor, colleagues, and customers (Clugston et al. 2000; Redman and Snape, 2005). The importance of the commitment to the organization, supervisor, and colleagues and the differentiation between them is discussed in many studies (Clugston et al. 2000; Vandenberghe, 2004, Wasti\& Can, 2007). As a result, it has been evaluated that employees develop different commitments to their relatively remote organizations, their representatives and closer supervisors and colleagues (Becker and Billings, 1993; Bishop and Scott, 2000): 1-)Affective Commitment to Organization, 2-Normative Commitment to Organization, 3-Affective Commitment to The Supervisor, 4-Normative Commitment to The Supervisor, 5-Affective Commitment to Colleagues and 5Normative Commitment to Colleagues.

It is considered that utilizing other non-organizational commitment foci and measuring affective and normative commitments within these contexts would provide more accurate and effective results in measuring organizational commitment (Wasti\& Can, 2007).

\section{The Effects of Toxic Leadership on Organizational Commitment}

With respect to negative leadership behaviours, studies have shown abusive leadership is negatively related to commitment (Rayner and Cooper, 1997; Tepper, 2000; Burris, Detert \&Chiaburu, 2008). Weaver and Yancy (2010) found that destructive leadership is inversely related to workers' affective commitment and positively related with the workers' intent to leave their organization. Mehta and Maheshwari' (2013) analysis reveal strong negative correlation between various factors of toxic leadership and variables of organizational commitment. Due to having negativity in the environment tend to negatively impact employee performance (Padilla, Hogan \& Kaiser, 2007). Extensive research has found that psychological conditions such as stress, depression, and anxiety experienced by employees can affect organizations through performance and productivity declines. For instance, Harris, Kacmar \&Zivnuska's (2007) study shows that abusive leadership is associated with a decrease in employee work performance.

Under toxic leaders, employees have essentially two options: obey or leave. Those who prefer to remain in the organization keep their hopes that situation might be changed. Some of them might respond by being only partly there. In other words, their commitment to their work and their connection with the company can be tentative. Arguably, commitment to an organization that allows destructive leadership should be low as followers might think that the organization fails to protect them (Burris, Detert, \&Chiaburu, 2008; Schyns\& Schilling, 2013). Thus, the employees may decrease their loyalty to the organization. On the other hand, research has shown that just as employees develop affective attachments to the organization, they also may feel committed to their supervisors either (Becker \& Billings, 1993; Clugston et al., 2000; Siders et al., 2001).

The main argument of this study is that there is a negative relationship between toxic leadership and organizational commitment as suggested in many studies. However, this study focuses on how commitment affects the commitment to the organization, co-workers, and supervisor. In this manner, we assumed toxic behaviours have negative effect on each commitment focus. Accordingly;

- H1: Toxic leadership is related negatively with commitment to organization.

- H2: Toxic leadership is related negatively with commitment to co-workers.

- H3: Toxic leadership is related negatively with commitment to supervisor

\section{RESEARCH QUESTIONS}

This paper seeks to find out how toxic leadership perceptions of employeesaffecttheirorganizational commitment in terms of three different foci. So, this paper has three main research questions:

1. How do the toxic leadership perceptionseffect commitment to organization?

2. How do the toxic leadership perceptionseffect commitment to co-workers? 
3. How do the toxic leadership perceptionseffect commitment to supervisor?

\section{PURPOSE OF THE STUDY}

The purpose of this paper is to describe and analyse the mutual relationships among toxic leadership perceptions, and organizational commitment. We decided to conduct our research on the employees of banking industry as the target pressures and performance expectations seem to be extremely high in this sector. Moreover, downsizing practices and massive failures in the banking industry have created fear and uncertainty which result with extremely high intention to leave and turnover rates (Cabral, 2004; Agbude et al.,2017). Accordingly, we assume that this kind of work environment is convenient for toxic leaders to emerge.

\section{RESEARCH METHODS}

The latent constructs were assessed using multi-item measures on a five-point Likert scale ranging from 'strongly disagree' (1) to 'strongly agree' (5) from prior studies. Short explanations of each measure are as follows. Toxic leadership as a five-dimensional second order construct composed of abusive supervision, authoritarian leadership, narcissism, self-promotion, and unpredictability was measured with a scale consisting of 30 questions adapted from Schmidt (2008). In order to measure the organizational commitment foci of commitment scale developed by Wasti\& Can (2008). Wasti and Can distinguish both among different forms (affective and normative) and different foci (organization, supervisor, co-workers) of commitment. Due to the focus of this paper we only used affective form of commitment. So, we have a three-dimensional organizational affective commitment scale with 5 questions for each dimension.

In order to empirically investigate the hypotheses, employees of seven banks -three private and four publiclocated in Kocaeli were surveyed. 6832 employees working in banks were recorded on the documents of The Banks Association of Turkey (https://verisistemi.tbb.org.tr). 600 among those 6832 we selected as the target group by random sampling technique. First the selected 600 employees were contacted by telephone and the aim of the study was explained to them. Of the 600 employees contacted, 331 agreed to participate in our study. Out of the 331 employees that agreed to participate, 299 employees completed the survey. After careful examination, all the incomplete returns with the missing data were discarded, leaving 277 responses for analysis. The findings are based on data from a convenience sample of which 277 of the participants were male (51\%). $87 \%$ of participants held university diplomas or higher degrees; $53 \%$ of the participants were working in public banks.

To more vigorously test the proposed model (see Fig. 01), partial least squares structural equation modelling (PLS-SEM) was employed with SmartPLS 3.0 statistical program.

To assess the psychometric properties of the measurement instruments, we estimated a null model with no structural relationships. We evaluated reliability by means of composite scale reliability (CR), Cronbach's alpha, and average variance extracted (AVE). After dropping the problematic three items for all measures the PLS-based CR and Cronbach's alpha are well above the cut-off value of .70, and AVE exceeds the .50 cut-off value. As suggested by Fornell and Larcker (1981), the AVE for each construct was greater than the squared latent factor correlations between pairs of constructs (see Table 01).

\section{TOXIC LEADERSHIP}

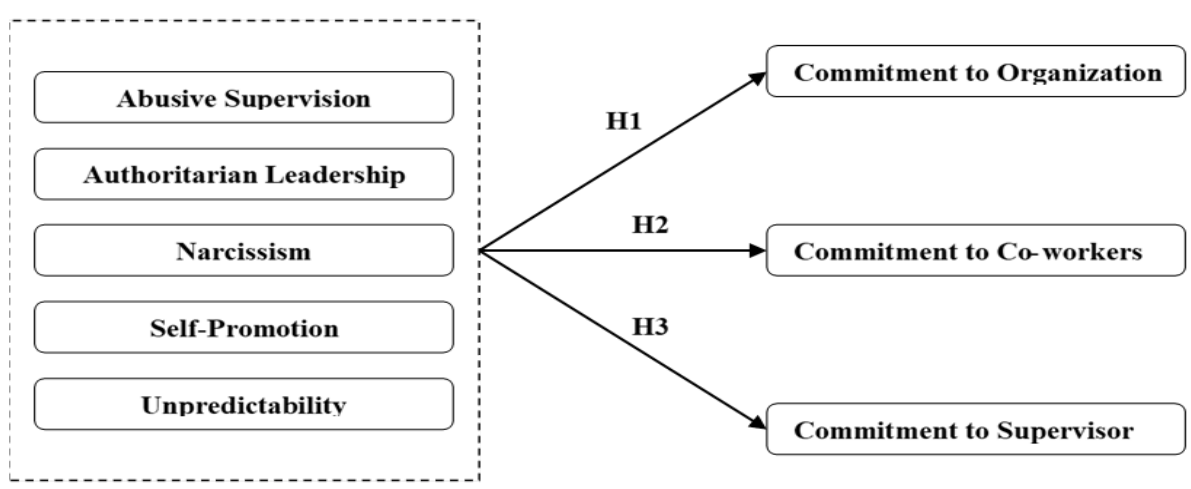

Figure 01. Theoretical Model 
Before conducting any path analyses, we conducted a second order factor analyse for the five components of toxic leadership; the results demonstrate that the five dimensions demonstrate loading between 0.870.93. So it is proper to take the toxic leadership as a composite variable instead of a five dimensional one. A composite toxic leadership variable will enable us to see the total effects of toxic leadership on affective foci of commitment.

Table 01. Discriminant Validity and Reliability Indicators

\begin{tabular}{cllllllll}
\hline Variables & $\mathrm{U}$ & $\mathrm{CC}$ & $\mathrm{AS}$ & $\mathrm{SP}$ & $\mathrm{N}$ & $\mathrm{CS}$ & $\mathrm{CO}$ & $\mathrm{AL}$ \\
\hline $\mathrm{U}$ & 0,736 & & & & & & & \\
$\mathrm{CC}$ & 0,497 & 0,826 & & & & & & \\
$\mathrm{AS}$ & $-0,495$ & $-0,349$ & 0,795 & & & & & \\
$\mathrm{SP}$ & $-0,444$ & $-0,255$ & 0,692 & 0,88 & & & & \\
$\mathrm{~N}$ & $-0,345$ & $-0,215$ & 0,7 & 0,79 & 0,872 & & & \\
$\mathrm{CS}$ & $-0,431$ & $-0,26$ & 0,72 & 0,77 & 0,692 & 0,85 & & \\
CO & 0,496 & 0,471 & $-0,371$ & $-0,304$ & $-0,233$ & $-0,32$ & 0,784 & \\
AL & $-0,411$ & $-0,303$ & 0,84 & 0,813 & 0,722 & 0,749 & $-0,297$ & 0,809 \\
& & & & & & & & \\
CR & $\mathbf{0 , 8 5 2}$ & $\mathbf{0 , 9 1 5}$ & $\mathbf{0 , 9 2 3}$ & $\mathbf{0 , 9 4 5}$ & $\mathbf{0 , 9 2 7}$ & $\mathbf{0 , 9 4 8}$ & $\mathbf{0 , 8 8 7}$ & $\mathbf{0 , 9 1 8}$ \\
AVE & $\mathbf{0 , 5 4 2}$ & $\mathbf{0 , 6 8 2}$ & $\mathbf{0 , 6 3 3}$ & $\mathbf{0 , 7 7 5}$ & $\mathbf{0 , 7 6}$ & $\mathbf{0 , 7 2 3}$ & $\mathbf{0 , 6 1 5}$ & $\mathbf{0 , 6 5 5}$ \\
$\boldsymbol{\alpha}$ & $\mathbf{0 , 7 8 3}$ & $\mathbf{0 , 8 8 5}$ & $\mathbf{0 , 9 0 2}$ & $\mathbf{0 , 9 2 7}$ & $\mathbf{0 , 8 9 4}$ & $\mathbf{0 , 9 3 6}$ & $\mathbf{0 , 8 4 7}$ & $\mathbf{0 , 8 9}$ \\
\hline
\end{tabular}

Note: $\mathrm{AS}=$ Abusive Supervision, $\mathrm{AL}=$ Authoritarian Leadership, $\mathrm{N}=$ Narcissism, $\mathrm{SP}=$ Self-Promotion, $\mathrm{U}=$ Unpredictability, $\mathrm{CC}=$ Commitment to Co-workers, $\mathrm{CS}=$ Commitment to Supervisor, $\mathrm{CO}=$ Commitment to Organization, $\mathrm{CR}=$ Composite Reliability, $\mathrm{AVE}=$ Average Variance Extracted, $\alpha=$ Cronbach's Alpha

\section{FINDINGS}

The PLS approach (Ringle et al., 2005) and the bootstrapping re-sampling method were employed by computing the SmartPLS 3.0 software program to test the hypothesis and predictive power of the proposed model (see Figure 01). T-statistics were calculated for all coefficients, based on their stability across the sub-samples, in order to determine the links that were statistically significant. The path coefficients and their associated t-values demonstrated the direction and impact of each hypothesized relationship. The findings demonstrated that toxic leadership is negatively and significantly associated with commitment to organization $(\beta=-.33 ; p<.01)$, commitment to supervisors $(\beta=-.31 ; p<.01)$, and commitment to coworkers $(\beta=-.49 ; \mathrm{p}<.01)$ supporting $\mathrm{H} 1, \mathrm{H} 2$ and $\mathrm{H} 3$.

Table 02. Results of Hypothesis

\begin{tabular}{llllll}
\hline Relationships & & & Path Coefficient $(\beta)$ & Hypotheses & Results \\
\hline $\mathrm{TL}$ & $\rightarrow$ & $\mathrm{CO}$ & $-0,329^{* *}$ & $\mathrm{H} 1$ & Supported \\
$\mathrm{TL}$ & $\rightarrow$ & $\mathrm{CC}$ & $-0,312^{* *}$ & $\mathrm{H} 2$ & Supported \\
$\mathrm{TL}$ & $\rightarrow$ & $\mathrm{CS}$ & $-0,492^{* *}$ & $\mathrm{H} 3$ & Supported \\
\hline
\end{tabular}

Note: $\mathrm{TL}=$ Toxic Leadership, $\mathrm{CC}=$ Commitment to Co-workers, $\mathrm{CS}=$ Commitment to Supervisor, $\mathrm{CO}=$ Commitment to Organization, $\mathrm{CR}=$ Composite Reliability, AVE = Average Variance Extracted, $\alpha=$ Cronbach's Alpha

The R2 statistic values of the endogenous constructs were used to assess model fit (Chin 1998; Tenenhaus et al., 2005). Table 03 shows R2 as the fit measures of the structural model. According to the results, commitment to organization $(\mathrm{R} 2=.15)$, and commitment to co-workers $(\mathrm{R} 2=.14)$ had medium level effect sizes while commitment to supervisors $(\mathrm{R} 2=.27)$, had large effect size. 
Table 03. Structural Model

\begin{tabular}{clc}
\hline Fit Measures & Endogenous Constructs & $\boldsymbol{R}^{\mathbf{2}}$ \\
\hline \multirow{2}{*}{$\boldsymbol{R 2}$} & $\mathbf{C S}$ & 0,27 \\
\cline { 2 - 3 } & $\mathbf{C O}$ & 0,15 \\
\cline { 2 - 3 } & $\mathbf{C C}$ & 0,14 \\
\hline
\end{tabular}

\section{CONCLUSION}

It clearly is essential to understand the consequences of toxic leadership in the workplace. In this study, we tried to find out whether the subordinates of toxic leaders have a lower affective commitment to their organization in terms of commitment to organization, commitment to co-workers, and commitment to supervisor. We find it does. Particularly this study has three main contributions

First, the findings of the study demonstrated that toxic leadership scale, which is developed in Western countries, are appropriate for an emerging economy and eastern country, Turkey. Measures demonstrated high validity and reliability, and model results were similar to the empirical studies completed in developed and western states.

Second, this study investigated the influence of toxic leadership on affective commitment from several foci -commitment to organization, commitment to supervisor, and commitment to co-workers-. The findings confirm statistically significant and negative associations between toxic leadership and all the foci of commitment. In other words, the abusive, narcissistic, unstable, selfish, and selfish behaviours of leaders probably result in subordinates developing negative work attitudes. Their commitment to organization, coworkers, and supervisors all together decrease. The negative feelings are reflected on all foci of commitment, not just the supervisor, which means higher negative consequences for both individual and organizational levels, just like intention to leave, counterproductive work behaviours, and decrease in productivity.

Third, the findings show that the impact of toxic leadership behaviours on commitment to supervisor is stronger than the associations of toxic leadership with other foci of commitment. This implies that even though the negative consequences of toxic leadership are reflected in the all foci of commitment, the main focus is on supervisors, in other terms, the leaders. Subordinates consciously direct their negative feelings to their managers.

The findings of this study cannot be taken as definite evidence because several limitations to the study results deserve commentary. First, this study is conducted on the employees of banking industry. Second, these results reported here emerge from a local area-Kocaeli-. Results may differ for employees of banking industry located on different areas that are operating in different cultural, environmental, and political conditions. Third, there was not an industrial separation while evaluating data; results may differ for various industries. Despite these limitations, this study provides essential results from theoretical and practical perspectives. This study indicates that toxic leadership is an important antecedent of affective commitment from several foci, and the negative effect of toxic leadership on commitment to supervisor is stronger than the other foci. Future studies may find it fruitful to enlarge the model by including new concepts like counterproductive behaviours, psychological well-being, and political behaviours. 


\section{REFERENCES}

Agbude, G. A., Obayan, A., Ademola, L. L. \& Abasilim, U. D. (2017), Leadership on trial: An Existentialist Assessment. Covenant International Journal of Psychology, 2(1).

Allen, N.J. and Meyer, J.P. (1990), The Measurement and Antecedents of Affective, Continuance and Normative Commitment to the Organization, Journal of Occupational Psychology, 63, 1, ss. 1-18.

Aubrey, D.W. (2012), The Effect of Toxic Leadership, Penny Hill Press Inc, March.

Barnes, B.L., Kriger, M.P. (1986), The Hidden Side of Organizational Leadership, MIT Sloan Management Review, Fall 1986, pp.15-26.

Bass, B. and Riggio, R. (2005), Transformational Leadership, 2nd ed., Lawrence Erlbaum and Associates, Mahwah, NJ.

Becker, E.T. (1992), Foci and Bases of Commitment: Are They Distinctions Worth Making, The Academy of Management Journal 35(1) March 1992.

Becker, E.T. and Billings R.S. (1993), Profiles of Commitment: An Empirical Test, Journal of Organizational Behavior (14) 1993, ss. 177-190.

Becker, H.S. (1960), Notes on The Concept of Commitment, American Journal of Sociology, 66, ss. 32 42.

Bishop, J.W. and Scott K.D. (2000), An Examination of Organizational and Tam Commitment ina SelfDirected Team Environment, Journal of Applied Psychology (85) 2000, ss. 439-450.

Burris, E. R., Detert, J. R.\&Chiaburu, D. S. (2008), Quitting Before Leaving: The Mediating Effects of Psychological Attachment and Detachment on Voice. Journal of Applied Psychology, 93(4), 912.

Byars, L., Neil,T.C. (1987), Organizational Philosophy and Mission Statements, Planning Review, April 1987, Vol. 15 No. 4, pp. 32-35.

Cabral, R. (2004), Turnover Theory/Intention to Leave in the Banking Industry. Association on Employment Practices and Principles, 45.

Chin, W. W. (1998), The Partial Least Squares Approach to Structural Equation Modelling. Modern Methods for Business Research, 295(2), 295-336.

Clugston, M., Howell, P.J. \& Peter W.D. (2000), Does Cultural Socialization Predict Multiple Bases And Foci of Commitment?, Journal of Management (26) No.1: 2000, ss. 5-30.

Einarsen,S., Aasland,M.S.\&Skogstad,A. (2007), Destructive Leadership Behavior: A Definition and Conceptual Model. Leadership Quarterly, 18(3), 207-216.

Erickson, A., Shaw,J. \&Agabe,Z.(2007), An Empirical Investigation of The Antecedents, Behaviors, and Outcomes of Bad Leadership. Journal of Leadership Studies, 1 (3), 26-43.

Fornell, C.\&Larcker, D.F.(1981), Evaluating Structural Equation Models with Unobservable Variables and Measurement Error. Journal of Marketing Research, 18 (1), 39-50.

Harris, K. J., Kacmar, K. M.\&Zivnuska, S. (2007), An Investigation of Abusive Supervision as a Predictor of Performance and The Meaning of Work as a Moderator of the Relationship. The Leadership Quarterly, 18(3), 252-263.

Horner, P. (1997), Leadership Theory: Past, Present and Future, Team Performance Management, December 1997, pp.270-287).

Jackson, T. A., Meyer, J. P. \& Wang, X. H. (2013), Leadership, Commitment, and Culture: A MetaAnalysis. Journal of Leadership \& Organizational Studies, 20(1), 84-106.

Karen, Wilson-Starks (2003), Toxic Leadership.

Kellerman,B. (2004), Destructive Leadership: What It Is, How It Happens, Why It Matters. Cambridge, Mass: Harvard Business School Press. 
Kusy, M. and Holloway, E. (2009), Toxic Workplace: Managing Toxic Personalities and Their Systems of Power, John Wiley \& Sons, ABD.

Lipman-Blumen, J. (2006), The Allure of Toxic Leadership: Why We Follow Destructive Bosses and Corrupt Politicians-And How We Can Survive Them, Oxford University Press, New York.

Mehta, S.\& Maheshwari, G. C. (2013), Consequence of Toxic Leadership on Employee Job Satisfaction and Organizational Commitment. Journal of Contemporary Management Research, 8(2).

Mehta, S.\& Maheshwari, G. C. (2013), Consequence of Toxic Leadership on Employee Job Satisfaction and Organizational Commitment. Journal of Contemporary Management Research, 8(2).

Meyer P. and Allen N.J., (1991), A Three-Component Conceptualization of Organizational Commitment, Human Resource Management Review, Vol:1, No:1, ss. 61-90.

Meyer, J. P.and Allen, N. J. (1997), Commitment in The Workplace, Theory, Research and Application, Sage Publications Inc., London.

Meyer, P.J. \& Allen J.N. (2004), TCM Employee Commitment Survey Academic Users Guide, ss. 2

Mowday, R.T. (1998). Reflections on The Study and Relevance of Organizational Commitment, Human Resource Management Review, 8, ss. 387-401.

Padilla, A., Hogan, R., \& Kaiser, R. B. (2007), The Toxic Triangle: Destructive Leaders, Susceptible Followers, and Conducive Environments. The Leadership Quarterly, 18(3), 176-194.

Paunonen,S.V., Lönnqvist, J.E., Verkasalo,M., Leikas,S. \& Nissinen,V. (2006), Narcissism and Emergent Leadership in Military Cadets. Leadership Quarterly, 17(5), 475-486.

Pelletier K. (2010), Leader toxicity: An Empirical Investigation of Toxic Behavior And Rhetoric, Leadership 6(4):373-389, November 2010

Powell, D.M. and Meyer, J.P. (2004), Side-Bet Theory and The Three Component Model of Organizational Commitment, Journal of Vocational Behavior, 65, ss. 157-177.

Rayner, C.\& Cooper, C. (1997), Workplace Bullying: Myth or Reality-Can We Afford to Ignore It? Leadership \& Organization Development Journal, 18(4), 211-214.

Redman, T., Snape, E. (2005), Unpacking Commitment: Multiple Loyalties and Employee Behaviour, Journal of Management Studies, Volume 42, Issue : 2005

Reed, G.E. (2004), Toxic Leadership, Military Review, 84(4), Ss. 67-71.

Ringle, C., Wende, S. \& Will, A. (2005), SmartPLS 2.0 (Beta). Hamburg, (www.smartpls.de).

Schmidt, A.A. (2008), Development and Validation of The Toxic Leadership Scale, Maryland University: Maryland, ABD.

Scholl, R.W. (1981), Differentiating Commitment from Expectancy as A Motivating Force, Academy of Management Review, 6, ss. 589-599.

Schyns, B. \& Schilling, J. (2013), How Bad Are The Effects of Bad Leaders? A Meta-Analysis of Destructive Leadership and Its Outcomes. The Leadership Quarterly, 24(1), 138-158.

Siders, M. A., George, G.\&Dharwadkar, R. (2001), The Relationship of Internal and External Commitment Foci to Objective Job Performance Measures. Academy of Management Journal, 44(3), $570-579$.

Tenenhaus, M., Vinzi, V. E., Chatelin, Y. M. \&Lauro, C. (2005), PLS Path Modelling. Computational Statistics \&Data analysis, 48(1), 159-205.

Tepper, B. J. (2000). Consequences of Abusive Supervision. Academy of management journal, 43(2), 178-190.

Vandenberghe, C., Bentein, K. \&Stinglhamber F. (2004), Affective Commitment to The Organization, Supervisor and Work Group: Antecedents and Outcomes, Journal of Vocational Behavior (64) 2004, ss. 47-71. 
Journal of Global Strategic Management | V. 14 | N. 2 | 2020-December| isma.info | 029-037 | DOI: 10.20460/JGSM.2021.291

Wasti,S.A.,Can, Ö. (2007), Bağlılık Odakları: Örgüte, Amire ve Çalışma Arkadaşlarına Bağlılık Ölçeklerinin Türkçe'de Geçerlemesi, XV. Ulusal Yönetim ve Organizasyon Kongresi, Sakarya Üniversitesi, ss. 735

Weaver, S. G. \& Yancey, G. B. (2010), The Impact of Dark Leadership on Organizational Commitment and Turnover. Leadership Review, 10, 104-124.

Yang, F. H., Wu, M., Chang, C. C. \&Chien, Y. (2011), Elucidating The Relationships Among Transformational Leadership, Job Satisfaction, Commitment Foci and Commitment Bases in The Public Sector. Public Personnel Management, 40(3), 265-278. 